DOI: 10.1515/ausp-2017-0022

\title{
A Logical Approach to Modal Verbs 1 Can and Could
}

\author{
Attila IMRE \\ Sapientia Hungarian University of Transylvania (Târgu-Mureş, Romania) \\ Department of Applied Linguistics \\ attilaimre@ms.sapientia.ro
}

\begin{abstract}
The article aims at a logical approach to discussing can, could, and be able to, organized around core meanings such as possibility, ability, and permission. We argue that the concept of "remoteness" proposed by Lewis in 1986 may simplify enough the explanation regarding the relationship between can and could, and their presentation relies on authoritative sources published for international (English), Hungarian, and Romanian students. The conclusion discusses both the importance and relativity of a number of occurrences (depending on different text types), trying to offer a possible teaching option for modals stemming from practice. The article is connected to the international conference in Miercurea Ciuc, entitled Idegen - Străinul - Stranger, focusing on English as a foreign language through the eyes of non-native speakers.
\end{abstract}

Keywords: modality, speech acts, remoteness, frequency, teaching modal verbs

\section{Introduction}

There are many warning statements about modal verbs, ranging from "problematic" or "complicated" to "messy" (Palmer 1990: 49), leading to a certain modal "abyss": whatever grammar book we consult in this respect, the approach is different, ranging from considering modals as irregular verbs (cf. some dictionaries) to the "ultimate" list of modal verbs, including or excluding certain entries (used to, have to, be to).

However, one of the grammar books highlights the importance of two rules regarding modal verbs, which may serve as a starting point: "modal auxiliaries occur in the first place in the verb phrase", and it is "not possible for them to cooccur with the others" (Lewis 1986: 100). These are very useful observations, but first we have to differentiate modal verbs from auxiliary verbs (be, have) or the emphatic $d o$, as all these may occur in the first place in a verb phrase: 
- be and have bear no meaning as auxiliary verbs, while modal verbs have their own meaning; do is basically the synonym of really or indeed, when used emphatically ( $I$ do love you.);

- as co-occurrence with other modal verbs is impossible, auxiliary verbs are not modal verbs:

You are being naughty today. He has had breakfast. I don't do that anymore.

- along the same line, few verbs may be considered modals; thus, they form a closed class with well-identifiable members;

- the membership of modal verbs may be extended to other verbs and constructions bearing certain modal forms and functions, which are considered marginal members.

There are more ways to refer to modal verbs: modals, modal-auxiliaries, defective modal verbs (lacking the majority of forms), anomalous or special finites, mood formers (Bădescu 1984: 383), even secondary auxiliaries (Greenbaum 1996: 153), although the term is not very logical, as they are always "first" in a string of verbs (cf. Greenbaum 1996: 260-266).

Even if modals express the "attitude of the speaker" (Palmer 1990: 2) in the form of specific concepts (possibility, necessity, politeness, etc.), a formal division is necessary (Quirk et al. 1980: 69; Quirk et al. 1985: 3-6; Swan 2005: 325-327), leading to:

1. central or core modals: can, could, may, might, shall, should, will, would, must;

2. marginal, peripheral, quasi- or semi-modals: dare, need, ought to, used to; have to, and be to may be listed here;

3. semi-auxiliary (modal) verbs and constructions are formally "outside the [modal] system" (Palmer 1990: 3), such as be able to or be going to;

4. modal idioms: had better, would rather, would sooner, have got to, could possibly, may well (Quirk et al. 1985: 137);

5. catenative constructions: appear to, come to, fail to, manage to, seem to, tend to, etc.

The extended view of modality makes it difficult to set boundaries for modals, making it virtually impossible to delimit them (Murvai 2001: 59). In the present article, we deal with can and could - so, it is important to briefly discuss features of central modals.

\section{Central modals. Form, function, and meaning}

Central modals have a single form for all persons and numbers, whatever the time reference, and so they violate the rule of "concord" between the subject and predicate (Quirk et al. 1985: 149). Furthermore, they take over major auxiliary 
functions: ${ }^{1}$ they help forming the interrogative and negative forms - including question tags, also making it possible to delete the lexical verb in short answers -, being always first-positioned in a verb phrase, which entails that modals are all considered transitive, whose direct object is the weak verb following them (Bădescu 1984: 403):

Jane might be watching the cranes flying over the city.

A most important remark is that there is no co-occurrence of modal verbs, meaning that it is not possible for two central modal verbs to follow each other in a verb phrase (Quirk et al. 1980: 75); however, a marginal modal verb may be preceded by a central modal verb:

You must be joking. (modal verb)

You will have to explain this. (not a central modal verb, as preceded by a modal verb)

Central modals are followed - exclusively - by either the short (bare) infinitive (I. verb form) or a perfect infinitive construction (modal + have + III. verb form): can breathe, must have arrived.

As categories tend to be fuzzy in the majority of cases (cf. Eleanor Rosch's prototype theory), even central modals lack minor features. For instance, can has no perfective construction in the affirmative, while may cannot be contracted with not (*mayn't), or must has no distinctive "past" form. Although formal features are important, the meaning of modals is of utmost importance as they are connected to modality and speech acts. A thorough description of modal verbs should mention both form and (communicative) function, but it should include inter-linguistic discussion as well, such as their possible translation(s) into other languages. In this respect, the English modals are rather complex as they may lead to three possibilities (for instance, Hungarian or Romanian):

1. they may have their "accepted" equivalents (word for word): can tud (Hu. 'able to'); can poate (Ro. 'able to', 'it is permitted');

2. they may be "represented" by a verb suffix: can -hat, -het (Hu. suffix to express possibility) or -na, -ne, -ná -né (Hungarian conditional suffixes); s-ar putea (Ro. 'it may be possible', which is the conditional mood in Romanian);

3. they may "disappear" in less polite translations: Can you help me? Segítesz? (Hu. 'Do you help me?'); Mă ajuți? (Ro. 'Do you help me?'), although conditional/ polite formulations are still possible (Hu. Segítenél?; Ro. Ai putea să mă ajuți?).

A justified question is whether modal verbs are "possible" to describe in a satisfactory (effective) way, as non-native speakers do need them in order to communicate successfully as modality is a natural companion to factual information. In fact, not much hope arises from Palmer's approach: "There is no doubt that the overall picture of the modals is extremely 'messy' and untidy and that the most the linguist can do is impose some order, point out some regularities,

1 See, for instance, the NICE properties in Huddleston (1976: 333). 
correspondences, parallelisms. But there is no single simple solution..." (Palmer 1990: 49).

A possible starting point is the native language, which may be rather different form English; for instance, Hungarian is a Finno-Ugric language, thus synthetic, with many suffixes and few tenses, while English belongs to the Indo-European branch, it is analytic with hardly any suffixes and a well-developed system of tenses, resulting in a string of even four verbs. These differences are immediately obvious when Hungarian students try to formulate their sentences in English:

Hu. Megehettük volna.

En. We could have eaten it.

The example clearly shows that the perfective combination with modal verbs belongs to the "realm" of intermediate, upper-intermediate, or advanced levels, as the first Hungarian word encapsulates a verbal prefix (Meg-), the root verb ( $e$ for enni), the suffix expressing possibility (-het), followed by the past tense marker $(t)$ and the first person plural marker (-ük); this is synthetic enough, but it is also completed with a perfective word referring to the past, suffixed by a hypothetical marker. While beginners can handle well conditional sentences type I (If you love me, I will marry you.), they will refrain from using conditional sentences type III (If you had loved me, I would have married you.), especially when the modal verb is different than would. Thus, it is plausible to discuss modal verbs after verbs, tenses, conditionals, and hypotheticals have been tackled with, although modal verbs pervade the entire English grammar, and the natural need of nonnative speakers drive them towards basic uses of central modal verbs, at least in "present"-case scenarios.

On the one hand, it is not only linguists who are interested in language, while on the other hand it is our firm belief that linguists do not have to "impose" anything, as rules of a language are not created by linguists, leading to further complications, beyond the range of the present article.

After having formally separated modal verbs from non-modal ones, their meanings must be also dealt with. It is also clear that objectivity and subjectivity must be included in the explanations, together with "basic" meaning and meaning deriving from the "context". Thus, rather subjective categories, such as politeness, may be discussed in terms of degrees instead of absolute rules, offering the chance to compare, for instance, can, could, may, and might. Some might accept can as perfectly polite (possibly completed with please), while others would prefer could.

The relationship between them and non-modal verbs may overlap in form, function, and meaning, leading to a desperate attempt to tackle them either individually, with a special focus on their form (affirmative, interrogative, and negative) and meaning (past, present, future reference), or constantly comparing them to each other to reveal (hidden) shades of meaning. As a full and systematic 
approach is near-impossible, we will try to follow a "personalized" approach in pairs, as modals represent "one of the most complicated problems of the English verb" (Lewis 1986: 99).

The time reference of modals is "now", more precisely when the speaker's utterance is voiced, paraphrased as "in the present circumstances, my judgment is that it is possible / necessary / desirable that ..." (Lewis 1986: 102) - so, their meaning is context-based, which is at least the length of an entire clause or sentence, if not a paragraph. The fact that not all modals have remote pairs further strengthens the idea that modals are not "designed" to express only temporal relationships. When used in interrogation, only the modality and not the entire proposition is questioned (Palmer 1990: 41), and the special meaning of modal verbs is reflected even in question tags:

John must not fail, mustn't he?

The example shows that the tag is meaning-based, as formally it would have required must.

\section{Modality and speech acts}

Modality is a semantic term taken from logic (Murvai 2001), dealing with judgements originating from the speakers' opinion and "attitudes" (Greenbaum 1996: 80) or the "speaker's assessment of probability and predictability" (Greere \& Zdrenghea 2000: 29), referring to (non-) factuality (truth value of utterances: certainty, probability, possibility) or reflecting "the speakers' judgment of the likelihood of the proposition it expresses being true" (Quirk et al. 1985: 219); the other option is "human" control over the situation (obligation, permission, intention, and the marginal ability).

These are readily expressed by modal verbs, although other verbs (hope), nouns (suggestion), adverbs (perhaps), and adjectives (able) also contribute to the full palette of modality. The shortest possible definition is that modality deals with non-factual or not actualized things, actions, or events (Aarts 2011: 275), while a well-summarized definition is that modality "refers to a speaker's or a writer's attitude towards, or point of view about, a state of the world. In particular, modals are used to say whether something is real or true, or whether it is the subject of speculation rather than definite knowledge" (Carter \& McCarthy 2006: 638).

Although there are many types of modality (e.g. alethic, buletic, axiological, temporal, rational, existential), grammar basically deals with three types:

- epistemic possibility is "concerned with knowledge and / or inference based on some evidence" or drawing conclusions (Aarts 2011: 276); as such, it is often arbitrary, subjective, referring to the possibility, prediction, or necessity of the situation; "something is or is not the case" (Palmer 1990: 50); 
- deontic obligation is connected to necessity, permission, or prohibition, "getting people to do things or (not) allowing them to do things" (Aarts 2011:276) or "what is required or permitted" either by authority or judgement (Huddleston \& Pullum 2005: 54), supposing that there is "some kind of human control over the situation" (Greenbaum 1996: 80);

- dynamic volition, ability, and courage (Huddleston \& Pullum 2005: 55), although these are neutral and circumstantial meanings (Aarts 2011: 277), as for instance - ability has little to do with subjective judgements, and it cannot be imposed.

The semantic and pragmatic value of these types of statements is definitely subjective (filtered through the "eyes" of the speaker), but there is an undeniable communication gain in the extended modal meaning (Murvai 2001: 68).

As our primary aim is can and could, we have to premise that all sources agree that these are connected to possibility, which makes it necessary to discuss speech acts.

The intricacy of speech acts derives from at least two various sources: first, how they may be expressed and secondly because they are highly subjective, resulting in ambiguous and overlapping semantic and pragmatic meanings and values. Speech acts may be expressed by the following options: declaratives as questions, modal verbs, interrogatives, and imperatives (Carter \& McCarthy 2006: 679-713). In our opinion, one of the most comprehensive summarizing table of speech acts belongs to Leech and Svartvik (2002: 128-151).

As speech acts are subjective, there are overlaps; for instance, expectation may be connected to both necessity ("I expect something because it must be done") and possibility ("I expect it because it can be done"); obstinacy may stem from volition refusal ("although I have to do it, I won't”), ability refusal ("I am able to do it, but I won't"), or logical deduction refusal ("I know this is going to happen, but I won't change anything about it”); advice may have multiple implications, depending on the social status of the speakers involved. 
Table 1. Leech \& Svartvik's speech acts

\begin{tabular}{|c|c|c|c|}
\hline A. LIKELIHOOD & $\begin{array}{c}\text { B. ATTITUDES TO } \\
\text { TRUTH }\end{array}$ & \multicolumn{2}{|c|}{ C. MOOD } \\
\hline $\begin{array}{l}1 \text { possibility } \\
\text { (+ tentative) } \\
2 \text { ability } \\
\text { (theoretical possibility } \\
3 \text { certainty/logical necessity } \\
4 \text { prediction/predictability } \\
5 \text { probability } \\
\text { (degrees of likelihood) }\end{array}$ & $\begin{array}{l}1 \text { certainty } \\
2 \text { doubt/uncertainty } \\
3 \text { belief/opinion } \\
\text { (assumption, } \\
\text { appearance) }\end{array}$ & $\begin{array}{l}\text { Volition } \\
1 \text { willingness } \\
2 \text { wish } \\
\text { (neutral, } \\
\text { hypothetical) } \\
3 \text { intentional } \\
4 \text { insistence }\end{array}$ & $\begin{array}{l}\text { Emotions } \\
1 \text { (dis)like } \\
2 \text { preferences } \\
3 \text { hope (tentative) } \\
4 \text { regret } \\
5 \text { wish } \\
6 \text { (dis)approval } \\
7 \text { surprise } \\
8 \text { concern } \\
9 \text { worry }\end{array}$ \\
\hline \multicolumn{2}{|c|}{ D. PERMISSION } & \multicolumn{2}{|c|}{ E. INFLUENCING PEOPLE } \\
\hline $\begin{array}{l}1 \text { permission } \\
2 \text { obligation/compulsion } \\
3 \text { "other" obligation } \\
\text { a. "internal" obligation } \\
\text { b. "strong" recommendation } \\
\text { c. "insistence" obligation } \\
\text { (official regulations, } \\
\text { formal documents) } \\
4 \text { involving future } \\
\text { a. warning } \\
\text { b. promise } \\
\text { c. threat } \\
\text { d. regret } \\
\text { e. offer }\end{array}$ & $\begin{array}{l}1 \text { prohibition } \\
\text { (negating permission) } \\
2 \text { "weakened" } \\
\text { prohibition } \\
\text { (negative advice) }\end{array}$ & $\begin{array}{l}1 \text { command } \\
\text { a. direct, impe } \\
\text { b. "politer" } \\
\text { c. using down } \\
2 \text { request } \\
\text { a. direct } \\
\text { b. "indirect" } \\
3 \text { advice } \\
\text { a. advice } \\
\text { b. suggest } \\
\text { c. invite }\end{array}$ & \\
\hline
\end{tabular}

We have also collected concepts of possibility, ranging from near-factual ("this is the case") to close to non-factual ("this is not the case") ones:

Table 2. Possibility, ability, necessity

\begin{tabular}{|c|c|c|c|}
\hline $\begin{array}{c}\text { inability } \\
\text { lack of ability }\end{array}$ & \multicolumn{2}{|c|}{$\begin{array}{c}\text { impossibility } \\
\text { lack of possibility }\end{array}$} & $\begin{array}{c}\text { unnecessary } \\
\text { lack of necessity }\end{array}$ \\
\hline $\begin{array}{c}\text { opportunity } \\
\text { ability } \\
\text { choice }\end{array}$ & \multicolumn{3}{|c|}{ POSSIBILITY } \\
\hline & $\begin{array}{c}|c| \\
\text { speculation } \\
\text { suspicion } \\
\text { doubt } \\
\text { hesitation }\end{array}$ & $\begin{array}{c}\text { likelihood } \\
\text { belief, conjecture } \\
\text { supposition }\end{array}$ & $\begin{array}{c}\text { logical necessity } \\
\text { probability } \\
\text { assumption } \\
\text { inference } \\
\text { deduction } \\
\text { prediction } \\
\text { conclusion } \\
\text { certainty }\end{array}$ \\
\hline
\end{tabular}

Although the degrees are subjective (e.g. near-impossibility/uncertainty probability - certainty), these concepts are typically associated with possibility. Modal verbs are often arranged on a scale of possibility (or synonymous terms such as likelihood): must, can't, could, may, might (cf. O'Connell 1999: 142-144). 
Remoteness (cf. Lewis 1986: 102) highly simplifies the way modal verbs are discussed as it offers a logical solution how the modal "pairs" should be treated: although we know that they are not the "present" and "past" pairs (can-could, may-might, will-would, shall-should), contradictions are used to prove it:

I'm lost now. Could you help me?

She can't have seen my brother yesterday, as he is in Darjeeling now.

The best explanation we have found so far is that each and every modal verb "is fundamentally grounded in the moment of speaking, at the point of Now" (Lewis 1986: 102), and so the concept of "remoteness" describes the relationship between the pairs, understood on multiple levels:

- remote in time: can "present/future" could "past"; when either can or could is followed by the perfective have + III. verb form, the context is past;

- remote in possibility/from facts: tentative, conditional, hypothetical constructions (If you can show me...; If you could just show me...);

- remote in volition/emotion: insistence (will) - indifference (could as well);

- remote in relationship: politeness (Can you tell me...? Could you tell me...?).

\section{CAN}

Can is arguably one of the most widely used modal verbs (the most frequent - cf. Carter and McCarthy 2006: 642), following will ${ }^{2}$ or even would ${ }^{3}$; however, it is sure that its importance cannot be neglected.

The core meaning of can is associated with objective possibility (Lewis 1986: 104) or perceiving the existence of possibility (Lewis 1986: 113), within which we can highlight ability, even if it is considered to be a marginal modal concept, because the speaker's judgement is of little importance. A more "diplomatic" view is that can represents a "semantic merger" of ability and possibility, as in case there is ability, then it is generally possible (Aarts 2011: 313).

Ability is an important concept (Newbrook \& Wilson 2001: 215-217), which is "best considered a special case of possibility" (Quirk et al. 1985: 221) or labelled as "extrinsic", "theoretical possibility" (Leech \& Svartvik 2002: 129); this probably means that it can be "activated" anytime. This is possible because ability is defined in the Shorter Oxford English Dictionary (Trumble \& Stevenson 2002: 5) and online ${ }^{4}$ as:

- "suitable or sufficient power" $\rightarrow$ strength;

- "capacity to do something” $\rightarrow$ inherent capacity, capability, possibility;

2 Cf.: http://www.ucl.ac.uk/english-usage/projects/verb-phrase/modalfindings.htm, retrieved on: 26.02.2017.

3 Cf. the top 3,000 English words [A 3000 leggyakoribb angol szó 2007].

4 https://en.oxforddictionaries.com/definition/ability, retrieved on: 24.02.2017. 
- "legal competency" $\rightarrow$ talk about permission;

- "a special power of the mind, a faculty" $\rightarrow$ knowledge, know-how, natural;

- "possession of the means or skill to do something" $\rightarrow$ skill, know-how;

- "talent, skill, or proficiency in a particular area" $\rightarrow$ learned, natural.

Although ability may be expressed by various verbs and expressions (be capable of, knows how to, manage, succeed, fail), it is most typically associated with can, could, and be able to, including their negative versions as well (can't, couldn't, be unable to), which usually express lack of ability. These may refer to past, present, or future, displaying a wide range of subtypes discussed within can, could, and be able to.

Can may express the following ability types (possibility of non-restriction, basically durable ones (Bădescu 1984: 407):

- Physical ability: John can lift a sack easily.

- Mental (cognitive, linguistic) ability or competence: John can remember all the missions. Jane can understand the importance of missions.

- Moral ability: You can do some good, for a change.

- Instrumental ability: Jane can't scythe, but she can play the guitar. (lack of ability, skill, competence)

- Sporadic, occasional ability (Gălățeanu-Fârnoagă 1995: 204), also referred to as existential (Aarts 2011: 291), circumstantial, or contingency ability: If cornered, Jane can be very dangerous. You can meet famous people at Cafe Blikle in Novy Świat. Bad things can happen very easily. (these are usually non-durable)

The interrogative form is rather puzzling as the ability in fact refers to a request (cf. Palmer 1990: 23):

Can you reach for the knife? ( I think you can; so, do it, please.)

- Sense verbs are typically associated with can: non-native speakers tend to omit the modal verb, overlooking the fact that the meanings are obviously different:

We can't hear as faint noises as dogs can. ("general" ability)

I can't see anything in this darkness. (impossibility to distinguish anything in a particular situation)

I can see you now. (non-durable possibility, similar to Present Continuous - cf. Gălățeanu \& Comişel 1982: 60)

I can't see why you're crying. (metaphorical impossibility: "I don't understand it.")

These types of ability are clearly part of possibility (cf. lack of "visible" evidence in case of ability versus evidence-based possibility), as - depending on the circumstances - these utterances may turn to tentative, hidden (im)polite requests and commands (She can be very fast [if she wants to]. She can be the chosen one.). Tentative (or conditional) ability is associated with opportunity or free choice (types of possibility connected to future), expressed by modal verbs 
(can, could) or certain phrases: If you want/would like/decide to ..., It's up to you (to decide), It's your call/choice/decision, Nobody will stop you if ..., The choice is yours. You will have the opportunity/possibility to ..., You're free to anything. The temptation (financial, moral, ethical, social, etc.) may remain theoretical or become strong enough anytime to trigger an event or reaction; hence the ability/ possibility aspect, leading to further uses:

- logical, objective, neutral, "generally and all time true" (Soars 2008: 153), dynamic possibility or impossibility, mostly referring to a single event: It's very cloudy. It can rain any time.

Possibility may have varying degrees (Budai 2007: 182), such as hypothetical solutions (It can be solved...) or imminent possibilities (If you turn right, you can see the castle.), connected to ability.

- temporary, "sporadic" possibility may lead to criticism (Vince 2009: 66): John can be lazy sometimes.

- (im)possibility may be decided by the law or rules (Preda 1962: 320): Say it quickly, as I can only talk on the phone for three minutes. (leading to permission)

- supposition, logical deduction combined with distrust, doubt or amazement (Preda 1962: 320): Can he behave like that in front of ladies? That pale guy can suffer from a serious disease.

- physical, moral, mental or legal impossibility (Lewis 1986: 104) associated with epistemic necessity (knowledge-based conclusion (Aarts 2011: 294)) expressing the confidence of the speaker (even if he may be wrong): You cannot be right about that. John can't pass the exam; he hasn't learnt an iota.

Past impossibility is expressed by can't + have + III. verb form:

Jane can't have met John in 2001. (I just don't believe it.)

The negative form may be part of a construction referring to impossibility stemming from personality or characteristic (Palmer 1990: 131): I just can't help smiling. ("It is just impossible for me not to smile.")

Another extended use of can is associated with permission, which is on the borderline between possibility ("once you are permitted, it is possible") and obligation: "an external authority" grants or refuses permission (cf. prohibition), while the person involved asks for the possibility of permission, without violating Fillmore's "sincerity" by disrespecting the social relationship between the interlocutors (1975: 224). This is an important observation as the possibility and permission senses of can overlap when used instead of may (Aarts 2011: 293):

- (rather impolite) asking for permission or requests may be associated with can, which is the spoken or informal (colloquial) alternative to the more polite and formal may: Can I take it? This is usually addressed to very close acquaintances although not recommended unless softeners are used (Can I take it, please?), or the verb is replaced (Can I have it?, Can I have it, please?). 
- a specific use is connected to courtesy (Palmer 1990: 78), which asks for permission:

Can I get you a drink? Can I ring you back?

-in case permission is granted, the dividing line between expressing permission (granting a request) and giving an order may be thin:

You can leave now. (1. That's not a problem. 2. You are let go.)

You can help your sister with her homework. (1. permission granted 2. reproach 3. order)

- talking about permission (Swan 2005: 100-102): We can bring anyone to the party. According to the law, you can defend your property. Passengers can have refreshments any time.

Can is also mentioned as expressing "freedom of constraint" against the constraint of can't (Wierzbicka 1996: 104-107), arguing that these are connected to fundamental human experiences, such as physical, moral, and social rules, power, opportunity, ability, skill, freedom, and wanting (God can do anything.), which corroborates the meanings of can presented so far. Further speech acts may be associated with can:

- order or command, which may be concealed (request) or not: Now you can both leave, I have heard enough. Can't we turn over a new leaf?

- the tentative ability or possibility may lead to mild suggestion or advice for future (Bădescu 1984: 419) instead of using the imperative, including even polite refusal or postponement (promise, possibility): I'm sure you can become $a$ successful lawyer. We can talk about it later. Can't we (just) stop now for a break? (the negative-interrogative form is used when expecting confirmation)

- offer to help (Budai 2007: 184), as a special type of suggestion (can combined with iff: I can clean your glasses if you want me to. If need be, we can raise money for the cause.

- agreement may be expressed with the help of an idiomatic expression: You can say that again.

- uncertainty or doubt (interrogative and negative forms): Now honestly, can you believe that he is in love with you? Can Jane have hidden the weapon in the attic?

- strong prohibition, in which case can't is an alternative to mustn't: You can't bring in weapons.

- can is emphasized in various (typically negative) feelings:

1. impatience, annoyance, surprise:

What can the colonel mean by "collateral damage"?

Now, what (on earth) can you tell about all your blunders?

2. irritation may be felt for typical, habitual actions (Budai 2007: 184):

You can be so rude sometimes.

The life and times of your neighbour can be boring, indeed. 


\section{COULD}

At this stage, we know that could is the remote pair of can (Lewis 1986: 112) regarding time (cf. reported speech or past ability), possibility and impossibility (less probability, more tentative and hypothetical, unfulfilled conditionals), criticism for not fulfilling expectations (could have + III. verb form), volition, and social relationship (polite formulations).

This approach makes way to various options for remote ability:

- Physical or general ability in a context-based past (cf. Murphy 1994: 52): John could lift two sacks of sand yesterday. However, the context may express actuality, referring to present (Palmer 1990: 96): John, how could you make it in time?

The grammatical past ability does not necessarily mean that it is fulfilled: John could have lifted two sacks of sand yesterday. (grammatical past)

- mental ability in the past: Jane could write at the age of five.

- "tentative" (present or future) ability (could combined with if), expressing various concepts: She could help you if you asked her. (advice)

- sense verbs associated with could refer to the past: Jane couldn't hear the orders clearly due to the heavy gunfire.

- hypothetical past ability (or possibility) which may turn to criticism on two reasons:

1. it is unfulfilled (Greenbaum 1996: 274), so the criticism is for not doing things (Swan 2005: 102): She could have helped you if you had asked her. (Why didn't you ask her?)

2. negative comparative structures with could suggest fulfilment above or below expectations (cf. Budai 2007: 187); Vince 2009: 65): Jane couldn't be more effective. Look around! I know, but she could be even better... John couldn't have been luckier (than meeting Jane).

Remote possibility is exemplified below:

- remote present possibility or mild suggestion (less certain, more tentative than can): John could be right ('I don't know better.'). I'm sure you could become a successful lawyer. ("one day")

- remote possibility (more distant from real possibility) may take the form of spontaneous asking for help: You couldn’t lend me €150,467 for that Ferrari, could you?

- supposition, deduction combined with distrust, doubt, or amazement (Preda 1962: 321): Could he behave like that in front of ladies? That bleeding guy could be telling the truth.

- impossibility with the negative form of could (at least the speaker is sure about that) or unwillingness (Vince 2009: 66): John couldn't be right about that. John couldn't possibly leave his comrade behind. 
An important remark is that when could is combined with all, the only one, nearly, and almost, it is associated with semantic negation (Palmer 1990: 95), which is only partially true for can: All Jane could do was to call for John. She knew that John was the only one who could negotiate successfully. John could almost wash all the dishes before Jane arrived home. Jane could nearly be taken by surprise during the first day of the mission.

- context-based past possibility: John could be there when the incident happened.

- past (im)possibility (Pawlowska \& Kempinski 1996: 121) or unfulfilled suggestion (could combined with if); could is less categorical than can (Preda 1962: 322): The colonel could have helped John. The colonel couldn't have known about his desperate situation. If she could have been the lead actor, she would have played in the film. You could have helped me if you had really wanted to. (unfulfilled possibility, reproach).

- past (im)possibility deriving from logical deduction: John could have arrived in Venice by now. Jane couldn't marry John because he was nowhere to be found. Now honestly, could she have eaten all the candies in five minutes?

Remote permission is also associated with could:

- "tentative" present/future permission (could combined with if): If Jane could be the lead actor, she would play in the film. (much more remote ask for permission than can)

- past permission: I could take only two candies from the tray. (I was allowed to ...) He couldn't use his fingers to count. (He wasn't allowed to...)

This case is connected to reported speech as the sentences above can be easily headed by an introductory sentence in the past: My mum said that I could take only two candies from the tray. The teacher told him that he couldn't use his fingers to count.

- remote permission results in an elevated degree of politeness (compared to can or would):

Could I take your pen?

Could I take your pen, please?

Could you (possibly) give me your pen, please?

I don't suppose you could give me your pen, could you?

Could I (possibly) have your pen, please?

The answer needs can or may (Zdrenghea \& Greere 1999: 258):

Yes, you may. No, you may not.

Yes, you can. No, you can't.

Further speech acts are also possible with could:

- doubt, uncertainty with various overtones (such as suspicion) or options (such as thinking aloud, internal monologue, or demonstrating it to someone): 
John could have arrived in Venice by now. Jane couldn't marry John because he was nowhere to be found. Could she have eaten all the candies in five minutes?

- utmost (bombastic) desire, impulse, ardent wish (Budai 2007: 188); GălățeanuFârnoagă 1995: 206): I could die for you. I could kill for a fag. John is so happy that he could promise the moon and the stars to Jane.

A ramification of this sense is connected to hypothetical (analytical subjunctive) constructions (Bădescu 1984: 409): If only you could understand my situation! Suppose we could obtain a lot of money easily, what would you buy? I wish you could have met the Does last night!

- suggestion (Vince 2009: 66): I could do you a favour. ("Just in case, you know.”)

- various (typically negative) feelings, possibly leading to extreme behaviour:

1. impatience (more express than can): How could he shoot like that? How could you do that to me? How (on earth) could John have sorted this out?

2. irritation, reproach, or criticism (for non-performance - Thomson \& Martinet 1986: 136): You could have helped me. Couldn't John have told us that he was going to get married? Why couldn't the colonel send more support?

3. mild reproach, scolding (also suggestion, advice): John could be a bit more attentive to details. You could stop presenting more examples.

The negative form is more explicit: Couldn't you stop treating her like a queen?

At this stage, a certain "urban legend" should be demystified, namely the issue of addressing to someone formally or informally ("thouing"). Although English is often regarded as a language which makes no difference between formal and informal way of addressing to people, modal verbs do reflect social closeness or remoteness, especially combined with first names or polite titles: $\mathrm{Mr}, \mathrm{Ms}$, Sir, Madam, etc. In this respect, can is used for friends, being "closer" than could, which should be used with strangers or politer ways of addressing people. However, could is not the only option for distancing, as verb choice (give versus have), adverbs (possibly, well), or the choice of first name or family name all contribute to the overall effect.

\section{BE ABLE TO}

Modal alternatives (modal paraphrases, alternative constructions, marginal modals, semi-modals) are needed to refer to more explicit past, present, or future reference as central modal verbs have only one form, and they may offer interesting shades of meaning compared to central modal meanings.

Be able to is a construction expressing ability, possibility, and necessity, gaining a more formal status (Palmer 1990: 90); so, it is "much more common in writing 
than in speech" (Palmer 1990: 103). Time reference is much easier to follow, and its future form is rather frequent (Budai 2007: 189), which also demonstrates that it is not a central modal verb (being preceded by will):

Jane was able to handle the situation alone.

I'm sure John will be able to carry out the mission successfully.

The colonel was sure that John would be able to carry out the mission successfully.

However, it should be noted that no modal alternative can fully replace the full set of a modal verb meanings. In this case, can and could typically refer to general ability or possibility (happening many times), while be able to is used to express:

a. single, specific, particular, and surprising ability (Dohár 2004: 81);

b. involving (overcome of) difficulty (Bădescu 1984: 411);

c. opposition (Gălățeanu-Fârnoagă 1995: 208);

d. becoming more stressed (Budai 2007: 188), especially that it can have degrees of comparison.

Possible alternatives are managed (to), succeed (to), while the negative scale is represented by fail (to), unable (to), couldn't:

I'm sure that Jane is able to understand this cryptic message.

John was able to do it again.

Jane is a person more able to handle the situation.

John is the person most able to negotiate with the rebels.

There are two options to construct the negative form (Budai 2007: 188): The colonel is not able to handle the situation. The colonel is unable to cope with stress.

A most interesting combination of grammar and culture is revealed by comparing can and be able to. While Palmer (1990: 90-99) argues that can means "can and will do" ("timeless" can) and be able to means "can and does", this is in fact the Miranda warning: ${ }^{5}$

Anything you say can and will be used against you in a court of law. ("anytime") John is able to handle the (this specific) situation.

\section{Conclusions}

As countless books and articles have been written on modality, we cannot claim that the present article brings too much novelty to the issue of modality and modal verbs. Nevertheless, the way we approach them tries to offer a wider perspective of can, could, and be able to, and, hopefully, a more logical one. Although the references come from authoritative native speaker authors (Cambridge and Oxford

5 Cf. non-violation of the Fifth Amendment to US Constitution: http://mentalfloss.com/ article/86769/10-facts-about-miranda-warning-you-have-right-know, retrieved 09.03.2017. 
publications), they still lack an important feature: why and how these modal verbs represent a problematic category for specific non-native speakers. This is why we checked important Hungarian, Romanian, and Polish publications, trying to summarize all relevant information regarding these modals.

We agree with Lewis that neither an over-simplification of the problem nor offering minor examples is the best solution; so, we have tried to succinctly collect uses of these modals and arrange them with the central organizing concept of remoteness. Thus, can and could may be described in a logical pair with modal concepts of possibility, ability, permission, etc.

Teaching modal verbs is an eternal challenge, but this does not mean that there are no successful options, starting from theory followed by practice, or concepts first and then exemplified with modal uses. A newer alternative might be facing the students with well-chosen samples, enabling them to formulate possible rules. In this respect, we can recommend a set of quotes and proverbs with can as a lead-in activity:

If you think you can do it, you can. (John Burroughs)

Whether you think you can, or you think you can't - you're right. (Henry Ford)

Any customer can have a car painted any colour that he wants so long as it is black. (Henry Ford)

In this world nothing can be said to be certain, except death and taxes. (Benjamin Franklin)

You can't make an omelette without breaking a few eggs.

You can't judge a book by its cover.

You can lead a horse to water, but you can't make him drink.

You can catch more flies with honey than with vinegar.

You can't have your cake and eat it too.

You can't teach an old dog new tricks.

Learners may wish to discuss and translate them, but it is obvious that this must be completed with "real-life" situations. TV series may be motivating enough to watch and check modal verb occurrences and frequency. One of our favourites is Castle, ${ }^{6}$ having 8 seasons with 173 episodes (combined) of at least 40 minutes' length each, that is 6,920 minutes, or more than 115 hours. It may be shocking to realize that the first season alone contains a multitude of can and could uses: 
Table 3. Can, could, be able to in Castle

\begin{tabular}{lccc}
\hline Castle, S1 E1-10 & CAN & COULD & be able to \\
\hline affirmative & 119 & 83 & 7 \\
\hline affirmative with negative meaning & 1 & & \\
\hline affirmative with interrogative meaning & & 2 & \\
\hline negative & 62 & 30 & 3 \\
\hline $\begin{array}{l}\text { negative with negative-interrogative } \\
\text { meaning }\end{array}$ & 2 & 1 & \\
\hline negative-interrogative & 2 & 1 & \\
\hline interrogative & 46 & 12 & 1 \\
\hline present/tentative & all & 63 & 6 \\
\hline past (modal + I.) & & 45 & 5 \\
past (modal + have + III.) & 20 & \\
\hline TOTAL & $\mathbf{2 2 6}$ & $\mathbf{1 2 8}$ & $\mathbf{1 1}$ \\
\hline & $\mathbf{3 6 5}$ & \\
\hline Similar meaning: capable 1, manage 7, succeed 1 & & \\
\hline
\end{tabular}

The table clearly shows some interesting cases:

Unless you can break his alibi on this one, he's a dead end.

You can't just say "night"?

What's the matter, sweetie? You can't hack it out there alone?

Why can't you just admit I was right?

Why can't they find bodies between 9:00 and 5:00?

I was wondering if I could take a moment of your time. (at a funeral)

So I could make the front page of "the ledger"?

Why couldn't we stick around?

However, the first season is a meagre $5.78 \%$ of the entire series, and so the potential number of can and could cases may be more than 6,000, offering a wonderful opportunity to collect interesting cases, leading to the importance of frequency. The importance of choice may be connected to the number of occurrences, especially when studying a foreign language at different levels. Although data may differ in various sources, it is worth looking into the statistics regarding modal verbs.

It is clear that the higher the frequency, the more situations are possible for a particular modal verb to be used, but non-modal factors still have to be considered. Will, for instance, is a suitable modal to function as the future operator (a term which may be applied, by and large, to the majority of auxiliaries and modals, involved in forming the negation and interrogation, although "imported" from logic). Aarts frequency table per million words (2011: 280) shows a high frequency for can (2,652 spoken $+2,533$ written), can't $(792+222)$, and cannot $(80+316)$, 
while shall has slightly over 400 occurrences. Yet, text type is relevant, as in one single EU document (146 pages) we found 616 (!) shall occurrences, while this number was only 2 for can, 10 for cannot, and not a single example was found for could. ${ }^{7}$ This is why the target audience must be considered, as - for instance - language exam students have different needs compared to translation and interpretation students.

While the use of can, could, and be able to referring to "present" circumstances is suitable for beginners and lower age-groups (Can you help me, please?), more advanced students can already distinguish the shades of politeness between can and could (cf. remoteness in social relationships) in the present (Could you do me a favour, please?), it takes much more time and practice to successfully use these modals in past contexts, especially when Hungarian or Romanian source sentences contain only suffixes that may indicate modal interpretations in English. This gradual shift from beginner to more advanced level is actually reflected when the word-for-word translation (Hu. tud, Ro. poate-En. can) turns to a suffix-for-word translation (Hu. -na, -ne, -ná, -né - En. could) in present conditionals. Anything beyond that (past context, passive, past unfulfilled conditionals, reported speech involving modals) is worth discussing at more advanced levels, making the students aware of the grammar areas they can handle whenever a new subject is dealt with.

\section{References}

Aarts, Bas. 2011. Oxford Modern English Grammar. Oxford-New York: Oxford University Press.

Bădescu, Alice. L. 1984. Gramatica limbii engleze [English Grammar]. Bucharest: Editura Ştiințifică şi Enciclopedică.

Budai, László. 2007. Élô angol nyelvtan. Rendszeres kontrasztív grammatika sok példával. [Living English Grammar. Contrastive Grammar with Many Examples]. Budapest: Osiris.

Carter, Ronald-Michael McCarthy. 2006. Cambridge Grammar of English: A Comprehensive Guide. Cambridge, England-New York: Cambridge University Press.

Dohár, Péter. 2004. Kis angol nyelvtan [A Little English Grammar] (17 ${ }^{\text {th }}$ ed.). Budapest: Ring6.

Fillmore, Charles J. 1975. May We Come In? In Santa Cruz Lectures on Deixis 1971, 220-234. Bloomington, Indiana: University of California, Berkeley.

7 Cf. www.europarl.europa.eu/committees/en/itre/draftreports.html?linkedDocument=true\&ufol derComCode $=$ ITREufolderLegId $=7 \&$ ufolderId=06804\&urefProcYear=\&urefProcNum $=\& u r e f P r o$ cCode; retrieved on: 12. 04. 2012. 
Gălățeanu-Fârnoagă, Georgiana. 1995. Sinteze de gramatica engleză: Exerciții şi teste de evaluare [Syntheses of English Grammar: Exercises and Evaluation Tests]. Bucharest: Cruso.

Gălățeanu, Georgiana-Ecaterina Comişel. 1982. Gramatica limbii engleze pentru uz şcolar. [English Grammar for Schools]. Bucharest: Editura didactică şi pedagogică.

Greenbaum, Sidney. 1996. The Oxford English Grammar. London: Clarendon Press.

Greere, Anca Luminița-Mihai Mircea Zdrenghea. 2000. A Guide to the Use of English Modals and Modal Expressions. Cluj-Napoca: Clusium.

Huddleston, Rodney. 1976. Some Theoretical Issues in the Description of the English Verb. Lingua 40(4): 331-383. https://doi.org/10.1016/00243841(76)90084-X.

Huddleston, Rodney-Geoffrey K. Pullum. 2005. A Student's Introduction to English Grammar. Cambridge, UK-New York: Cambridge University Press.

Leech, Geoffrey-Jan Svartvik. 2002. A Communicative Grammar of English (3 ${ }^{\text {rd }}$ ed.). London-New York: Routledge.

Lewis, Michael. 1986. The English Verb: An Exploration of Structure and Meaning. Hove: Language Teaching Publications.

Murphy, Raymond. 1994. English Grammar in Use with Answers (2 ${ }^{\text {nd }}$ ed.). Cambridge: Cambridge University Press.

Murvai, Olga. 2001. Szemantikai és pragmatikai kiegészítések a modalitás vizsgálatához [Semantic and Pragmatic Addition to the Study of Modality]. In János Petőfi S.-Irma Szikszainé Nagy (eds), Grammatika - szövegnyelvészet szövegtan [Grammar - Text Linguistics - Textology], 59-69. Debrecen: Kossuth Egyetemi Kiadó.

Newbrook, Jacky-Judith Wilson. 2001. Proficiency Gold. Harlow: Longman.

O'Connell, Sue. 1999. Focus on Advanced English: C.A.E. for the Revised Exam. Harlow: Longman.

Palmer, Frank R. 1990. Modality and the English Modals. London-New York: Longman.

Pawlowska, Barbara-Zbigniew Kempinski. 1996. Teste de limba engleză. [English for Examinations]. Bucharest: Teora.

Preda, Ion A. 1962. Verbul I. Clasificări [The Verb I. Classifications]. In C. George Săndulescu-Lidia Vianu (eds), Gramatica limbii engleze [English Grammar], vol. 4, 265-380. Bucharest: Universitatea din Bucureşti.

Quirk, Randolph-Sidney Greenbaum-Geoffrey Leech-Jan Svartvik. 1980. Grammar of Contemporary English. Longman.

1985. A Comprehensive Grammar of the English Language ( $2^{\text {nd }}$ ed.). LondonNew York: Pearson Longman. 
Soars, Liz. 2008. New Headway Advanced Student's Book: English Course. Oxford: Oxford University Press.

Swan, Michael. 2005. Practical English Usage (3 ${ }^{\text {rd }}$ ed.). Oxford: Oxford University Press.

Thomson, Audrey Jean-Agnes V. Martinet. 1986. A Practical English Grammar ( $4^{\text {th }}$ ed.). Oxford: Oxford University Press.

Trumble, William R.-Angus Stevenson, eds. 2002. The Shorter Oxford English Dictionary ( $5^{\text {th }}$ ed., vol. II). Oxford: Oxford University Press.

Vince, Michael. 2009. Advanced Language Practice: Student Book Pack with Key ( $4^{\text {th }}$ ed.). Oxford: Macmillan Education.

Wierzbicka, Anna. 1996. Semantics: Primes and Universals. Oxford: Oxford University Press.

XXX. 2007. A 3000 leggyakoribb angol szó. [The 3,000 Most Frequent English Words]. Budapest: www.Best-English.eu.

Zdrenghea, Mihai Mircea-Anca Luminița Greere. 1999. A Practical English Grammar. Cluj-Napoca: Clusium. 